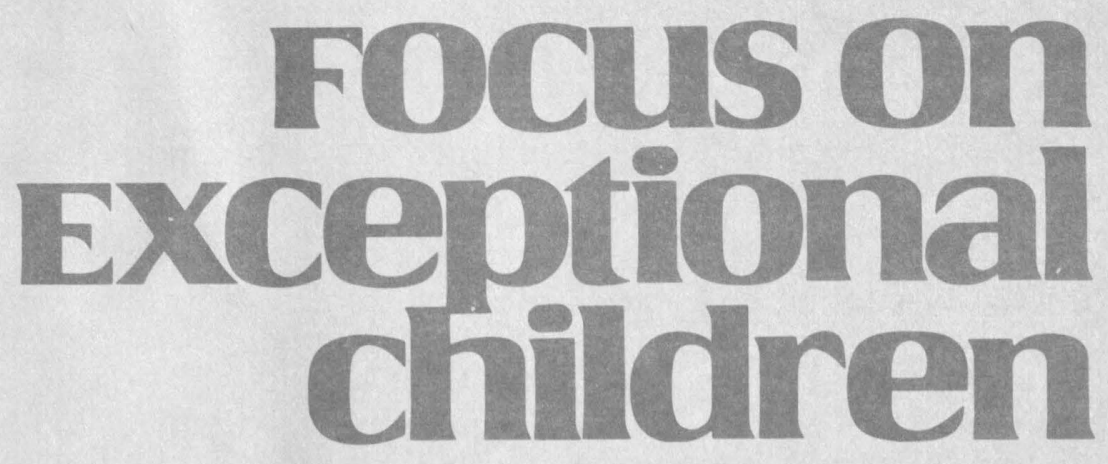

\title{
Developing a Consulting Program in Special Education: Implementation and Interventions
}

\author{
Lenny Reisberg and Ronald Wolf
}

Service delivery models used to educate handicapped students have been influenced by a variety of factors. Requirements in Public Law 94-142 to educate students in the least restrictive environment, research examining the efficacy of special education programs (Dunn, 1968; Goldstein, Moss, \& Jordan, 1965; Sindelar \& Deno, 1978), research into the effects of labeling (Hobbs, 1975; Reger, 1979), and criticisms of current identification practices (Ysseldyke, 1979, 1983) have encouraged schools to educate handicapped students in environments other than self-contained settings. The direction toward educating handicapped students in the least restrictive environment has had the greatest impact upon individuals identified as mildly handicapped. This includes students in the categories of behavioral disorders, learning disabilities, and mild mental retardation, as well as students referred to as slow learners, underachievers, or educationally handicapped (Deshler, Schumaker, Alley, Warner, \& Clark, 1982; Madden \& Slavin, 1983).

To educate mildly handicapped students in the least restrictive environment, special education efforts historically have attempted to provide direct academic interventions in resource room settings to improve students' academic skill achievement and thus allow the students to function effectively in the regular classroom. One important assumption in this model is that mildly handicapped students can be appropriately educated largely in regular education settings, and one means of achieving this goal is to improve the cooperation between regular and special education teachers.

Although educators have achieved no consensus, research and professional opinion have supported efforts to provide appropriate education programs for mildly handicapped students within the regular classroom setting (Bickel \& Bickel, 1986; Wang \& Birch, 1984). The utilization of sound instructional practices is thought to meet the needs of a large number of special education students while allowing them to remain in the regular classroom (Heller, Holtzman, \& Messick, 1982). Placing handicapped students in regular classes, however, has placed increased instructional and management demands on regular classroom teachers (Gerber, 1986). Therefore, to educate handicapped students in the least restrictive environment, regular educators must receive supporting and collaborative services from special educators.

Dr. Reisberg is Chairperson of the Special Education Unit of the School of Education, Pacific Lutheran University. Dr. Wolf is Research Assistant Professor of Special Education, West Virginia University. 
The focus on consultation and collaboration between special and regular educators has a long history of support (Wiederholt, Hammill, \& Brown, 1983; Aloia, 1983), but integrating this model with the research and suggestions offered by school improvement (Goodlad, 1984; LoucksHorsley \& Hergert, 1985; Pratzner, 1984) and effective school research (Good \& Beckerman, 1978; Hunter, 1984; Rosenshine, 1983; Stallings \& Kaskowitz, 1974) is needed to best educate handicapped students in the mainstream. Toward this end this article will focus on implementation of a consulting teacher model and on effective interventions for mildly handicapped students in regular education settings.

\section{CONSULTATION RATIONALE AND BACKGROUND}

\section{Definitions}

Numerous definitions have been set forth for consulting and what may encompass consultant programming efforts

\section{FOCus on
Exceptional children}

FOCUS ON EXCEPTIONAL CHILDREN (ISSN0015-511X) (USPS 203-360) is published monthly except June, July, and August as a service to teachers, special educators, curriculum specialists, administrators, and those concerned with the special education of exceptional children. This journal is abstracted and indexed in Exceptional Child Education Resources, and is also available in microform from Xerox University Microfilm, Ann Arbor, Michigan. Subscription rates: Individuals, $\$ 24$ per year; institutions, \$30 per year. Copyright ${ }^{\circ} 1986$, Love Publishing Company. All rights reserved. Reproduction in whole or part without written permission is prohibited. Printed in the United States of America. Second class postage is paid at Denver, Colorado.

POSTMASTER: Send address changes to:

Love Publishing Company

Executive and Editorial Office

1777 South Bellaire Street

Denver, Colorado 80222

Telephone (303) 757-2579

\section{EDITORIAL BOARD}

$\begin{gathered}\text { Edward L. Meyen } \\ \text { University of Kansas }\end{gathered}$
Richard J. Whelan
Georgia State University

(Cohen, 1982; Hawisher \& Calhoun, 1978; Idol-Maestas, 1983). For purposes of this paper, we will base our programming suggestions on the definition offered by Idol-Maestas. This definition identifies consultation as any support offered to regular classroom teachers to assist them in the education of mildly handicapped students. Furthermore, Idol-Maestas suggested that to facilitate mainstreaming, teachers must spend $20 \%$ to $40 \%$ of their school day in consultation-related activities.

Although this definition may be somewhat broad in scale, it does provide personnel a framework from which to focus their programming efforts. Consulting tasks may include discussing educational problems, presenting ideas for use in the regular classroom, inservice, coordinating programs, observing in the regular classroom, performing curriculumbased assessments, and demonstrating instructional techniques (Knight, 1976; Wiederholt, Hammill, \& Brown, 1983).

The consultant role for special education personnel has received a great deal of support within current literature (Friend, 1984; Idol-Maestas, 1983; Lilly \& Givens-Ogle, 1981; Paolucci-Whitcomb \& Nevin, 1985). The goal of helping special education students "catch up" with their nonhandicapped peers by receiving instruction in resource room settings only has resulted for many in further isolation and discrepancy from the task demands of the regular classroom setting (Salvia \& Ysseldyke, 1985; Ysseldyke \& Algozzine, 1983). Special education services delivered in settings outside the regular classroom or with supplantive curriculum materials rather than with curriculum used in the regular settings may be criticized as leading to a fractionalized set of goals and objectives and for lacking

\section{STATEMENT OF OWNERSHIP AND} CIRCULATION

Date of Filing: September 30, 1986

Title of Publication: FOCUS ON EXCEPTIONAL CHILDREN

Frequency of Issue: Monthly except June, July and August

Location of Known Office of Publication: 1777 S. Bellaire St., Denver, CO 80222

Location of Headquarters of Publisher: 1777 S. Bellaire St., Denver, CO 80222

Name and Address of Publisher, Editor, and Managing Editor: Stanley F. Love, 1777 S. Bellaire St., Denver, CO 80222

Owner: Stanley F. Love

Extent and Nature of Circulation:

$\begin{array}{lcc}\text { Total No. Copies Printed } & \begin{array}{c}\text { Average No. Copies } \\ \text { Each Issue during } \\ \text { Preceding 12 Months }\end{array} & \begin{array}{c}\text { Single Issue } \\ \text { Nearest to } \\ \text { Filing Date }\end{array} \\ \text { Paid Circulation } & 3,590 & 3,330 \\ \quad \text { Sales through Dealers, etc. } & 0 & 0 \\ \quad \text { Mail Subscriptions } & 2,985 & 2,775 \\ \text { Total Paid Circulation } & 2,985 & 2,775 \\ \text { Free Distribution } & 250 & 200 \\ \text { Total Distribution } & 3,235 & 2,975 \\ \text { Office Use and Left Over } & 355 & 325 \\ \text { Total } & 3,590 & 3,300\end{array}$

I certify that the statements made by me above are correct and complete. 
generalization and transfer to the regular setting (AndersonInman, Walker, \& Purcell, 1984; Idol-Maestas, 1983; Ito, 1980; Vaac, 1975). Social and academic isolation of mildly handicapped students from the mainstream setting has led educators to suggest greater coordination between regular and special education (Stainback \& Stainback, 1984). This is supported by evidence suggesting that many mildly handicapped students can profit from a variety of instructional practices delivered within the regular classroom (Knight, Meyers, Paolucci-Whitcomb, Hasazi, \& Nevin, 1981; Miller \& Sabatino, 1978; Wang \& Birch, 1984; Wixson, 1980).

\section{The Need for Consultation}

Several studies have found that regular classroom teachers possess negative attitudes toward mainstreaming (Gallagher, 1985; Hudson, Graham, \& Warner, 1979; Ryor, 1978). Also, Idol-Maestas and Ritter (1985) reported that some $22 \%$ of recent graduates from a consultant preparation program found colleagues resistant to consultation. Other studies have shown that regular educators perceive themselves as lacking skills and needing assistance to successfully implement mainstreaming (Hudson, Reisberg, \& Wolf, 1983; Ryor, 1978).

A study by Speece and Mandell (1980) found that regular education teachers rated nine support services as critical for effective mainstreaming but that these services were provided infrequently. Among these were: meeting informally to discuss student programs, scheduling meetings to evaluate progress, and providing and suggesting materials for classroom use.

Contrasted with regular educators' resistance to mainstreaming and the stated need for support and assistance, the perceived need by teachers in the field of special education for training in specific consulting skills is not conclusive when reviewing the existing literature. Teachers express need for a consultant role but identify only very global areas in which they think further training may be needed (Friend, 1985). In contrast to teachers' perceptions of their need for further training, Aloia (1983) found that special educators rated themselves as being less competent and confident in their ability to work as consultants when compared to their ability to deliver direct instruction and meet their role demands as resource room teachers.

Schmid, Algozzine, Wells, and Stoller (cited in Mercer, 1983) reported that surveyed special education teachers ranked consulting with regular educators seventh when identifying teacher goals from most to least important. The same group identified remediation of academic skills as the most important teaching goal. Not surprisingly, these same teachers reported that their time spent in consulting with regular educators was fourteenth of fifteen identified tasks.

In other studies (Evans, 1980; Neel, 1981; Vasa, 1982) resource room teachers reported spending $5 \%$ to $7 \%$ of their school day in consultation-related activities. These data may not be a reflection on the perceived need for special educators to serve as consultants to regular educators but more a reality of the time constraints placed upon special educators' daily schedules. Teachers may be saying that while they support a consultant role within the school system, they do not have the time to do it without some modifications in their job descriptions and role.

Additional data that seem to support this notion have been presented by Idol-Maestas and Ritter (1985). In a survey of recent graduates from a resource/consulting teacher program, over one-half of the 24 teachers reported that consultation was one of their responsibilities but that time constraints were a major obstacle in their ability to function in that role. Other barriers reported by the teachers were: failure to promote the consultant role; failure to develop a specific program or plan for consultation; and lack of administrative or colleague support.

Still other information related to skill development for the consultant role, as reported by teachers, has pointed up a lack of specific training in a variety of areas (Friend, 1984; Haight \& Molitor, 1983). These usually have focused upon global areas of conducting inservice training, human relations, public relations, and counseling. Aloia (1983) found that special educators rated themselves as significantly less able to consult with regular educators in the areas of informal assessment, formal assessment, staff relations skills, parent relationships, and use of paraprofessionals. These findings would seem to indicate that teachers' greatest concerns lie in the areas of "how to" consult rather than upon the specific content to be delivered.

Although we strongly support the need for special educators to develop facilitative interpersonal communication skills, this article takes a different perspective-focusing instead on the content of the information that consultants will share and upon overcoming the administrative and attitudinal barriers to consultation. The same curricular approaches or instructional procedures that have been employed in the special education setting may not be appropriate for the regular classroom. Likewise, teachers' reports of lack of time and administrative support for their role as consultants call for an implementation approach that minimizes resistance and facilitates shared responsibility and ownership. (Readers are referred to DeBoer, 1986, for details on the communication process not addressed in this paper.) 


\section{CONSULTATION MODELS}

Various consultant models have been identified and delineated for numerous occupations and philosophical orientations. These include clinical, mental health, education and training, and behavioral-to name a few (Bergan, 1977; Gallessich, 1982; Tombari \& Davis, 1979). A report prepared by Dissemin/Action on consultation programs nationwide identified 24 college and university programs designed to prepare special educators to serve as consultants (IdolMaestas et al., 1985).

To date, most consultant models and teacher preparation programs have relied heavily on a behavioral orientation (Cipani, 1985; Heron \& Harris, 1982; Knight, Meyers, Paolucci-Whitcomb, Hasazi \& Nevin, 1981). This perspective concentrates on targeting problem areas resulting from a consultee's lack of training or experience and delineating these problems in observable, measurable terms. Interventions then are developed to either increase or decrease the target behaviors. In the behavioral models heavy emphasis is placed upon procedures for specifying goals and objectives, collecting data, and evaluating student performance.

A process approach (Brokes, 1975) also is generally advocated, emphasizing a cooperative approach to problem identification, problem solving, and a shared responsibility for implementing solutions. This client-centered approach is designed to promote cooperation and teacher independence and to minimize resistance.

One model for behavioral consultation has been proposed by Cipani (1985). This model incorporates a three-phase approach and a content focus within a consultant's role. Its goals are the identification of learner behaviors, interventions, and evaluation. Cipani has referred to these tiers as: (a) developing consultation objectives; (b) designing and implementing objectives; and (c) implementing quality assurance. In short, this is a program approach to implement principles of applied behavior analysis in developing prescriptions for the regular classroom setting.

The University of Illinois Resource/Consulting Teacher Program is an example of a teacher education program designed to prepare consulting teachers (Idol-Maestas, Lloyd \& Lilly, 1981; Idol-Maestas, 1983). This program has a two-tiered approach to training. Students are trained in both the process and content of consultation. The process emphasizes effective problem-solving and communication skills, and the content stresses empirically-based instructional methods. These methods include applied behavioral analysis, direct instruction, mastery learning, repeated reading, peer and cross-age tutoring, curriculum-based assessment, behavior modification, generalization training, and material modification.
Project ConSEPT at Pacific Lutheran University (IdolMaestas et al., 1985) consists of a two-course, 6-semesterhour program designed to prepare graduate students to function as consultants. The two consultation courses are part of a 32-semester-hour master's program. Project ConSEPT shares a philosophy similar to that of the Illinois model. One course is directed at the content of consultation, including implementation strategies, data-based instruction, curriculum-based assessment, peer and cross-age tutoring, direct instruction, cooperative learning groups, and generalization. The second course covers interpersonal communication skills including effective listening skills, providing feedback, developing empathic and respectful response styles, and developing problem-solving strategies.

The Vermont Consulting Teacher Training Program (Paolucci-Whitcomb \& Nevin, 1985) is another comprehensive program approach based upon behavioral principles for consulting (Bergan, 1977). It has been described as a teacher training model (Lilly, 1972) with a triadic perspective of consultation (Tharpe, 1975). This view identifies three factors in the consultant process: (a) the consultant, (b) the mediator, and (c) the target learner. A major objective of the program is to develop consultants' skill levels that will enable them to influence the relationship between the mediator and the targeted learner. The mediator-in this case, the regular classroom instructor-is identified as the change agent, or the person responsible for delivering the intervention to the student(s). The consultant facilitates the problem-solving process, serving as a resource and sharing responsibility with the regular classroom teacher for identification of the appropriate content and instructional process.

Other consulting programs (Idol-Maestas et al., 1985) share the common philosophy that with appropriate planning and interventions, appropriate educational programs can be provided to mildly handicapped students largely in mainstreamed settings. Although proponents of the consulting model have reported data supporting this notion (Knight, Meyers, Paolucci-Whitcomb, Hasazi \& Nevin, 1981; Miller \& Sabatino, 1978; Wang \& Birch, 1984; Wixson, 1980), obstacles to adopting a successful consulting program occur in implementation and development of effective content for mainstream programs. Teachers wishing to serve as consultants have noted a lack of time and administrative support for consultation (Idol-Maestas \& Ritter, 1985), as well as teacher resistance to mainstreaming (Gallagher, 1985).

The following section will discuss methods for effectively implementing a consulting teacher model. Then suggestions for appropriate interventions for the regular classroom will be given. 


\section{Implementation}

One model designed to foster the implementation of a consulting teacher model is Project RETOOL (McClellan $\&$ Wheatley, 1985). A federally funded project, it offered training in collaborative consultation skills to faculty teams from teacher education programs around the country. These teams, consisting of three faculty members with specialization in administration, regular education, and special education, then provided turn-around training in consultation skills to their colleagues and, through preservice and inservice programs, to teachers and local education agencies. Teams from 12 universities were trained in the model, and a multiplier effect was realized as these teams provided turnaround training in their regions.

Other models such as Pacific Lutheran University's Project ConSEPT and the University of Illinois' Resource/Consulting teacher program, focused on preparing consultants through preservice courses. In these programs students may be required to participate in consultation projects, develop communication skills, complete research in consultation, and develop instructional skills appropriate for the mainstream.

\section{Barriers}

As these trained teachers return to their schools and attempt to develop a consulting teacher model, a variety of obstacles must be addressed. As reported by Idol-Maestas and Ritter (1985), teachers may face barriers to implementing their role as consultants. One factor they noted was the teachers' failure to promote or negotiate for the inclusion of consultation in their job descriptions. Teachers may initially feel uncomfortable in the role of consulting teacher and feel more secure in providing direct services only. One teacher in the Project ConSEPT program with more than 12 years of special education teaching experience reported feeling just like a "student teacher" when thrust into a role of consultant.

The value of networks (Quinby, 1985) - teachers working together to overcome problems-may help address this problem. If teachers with similar goals can communicate and problem-solve on a regular basis, they lend support and fresh ideas to each other.

Lack of administrative support also may be a barrier to development of a consulting teacher program (Idol-Maestas \& Ritter, 1985). Involvement by administrators in the planning and implementation phases of the project is critical. Quinby (1985) and Goodlad (1984) have noted the important role that administrative leadership plays in setting the tone for school improvement. The result of a lack of prior involvement may be initial resistance and a lack of support not only by administrators but also by teachers who follow their lead. The involvement and support of building and district administrators may well set the tone for the project's acceptance and success.

Time for consultation also is noted by Idol-Maestas and Ritter (1985) as a barrier to implementing a consultation program. In order to consult, special education teachers must have a job description that includes consultation as a primary duty and must be given sufficient time to provide those consultative services. Release time from in-class instructional responsibilities is necessary. Teachers may be released for one or more periods each day or may reserve one day each week for consulting.

The decision on whether to release time on a daily or weekly basis must be made individually in each district or school and is dependent on the flexibility of the school's scheduling procedures. The bottom line, however, is that a consultation program is not possible without time allocated for consulting, and this requires that teachers have release time from in-class instructional responsibilities.

Means to overcome these barriers to consultation must come in the initial stages of developing and proposing the model. Development of a consultation program in the school must be seen as similar to other school improvement programs-requiring careful planning, cooperative decision making, involvement of all affected groups, and sufficient time to be developed, implemented, and evaluated.

\section{Steps in Implementation}

Loucks-Horsley and Hergert (1985) have developed a seven-step model for establishing a school improvement project. These steps consist of : (1) establishing the school improvement project, (2) assessment and goal setting, (3) identifying the ideal solution, (4) preparing for implementation, (5) implementation, (6) review of progress and problems, and (7) maintenance. Sparks, Nowakowski, Hall, Alec, and Imrick (1985) developed a model for staff development and change resting on six steps involving: (1) development of readiness, awareness, and commitment, (2) needs assessment, (3) planning, (4) implementation, (5) evaluation, and (6) reassessment and continuation.

Like any change, a school improvement project is a difficult process - apt to be met with some anxiety and resistance from a number of sources. The models proposed by Loucks-Horsley and Hergert and Sparks et al. are designed to help facilitate acceptance and successful implementation 
of school improvement programs. The steps suggested are not intended to be viewed as rigid, sequential steps (LoucksHorsley and Hergert suggested that some of their proposed steps may be implemented simultaneously) but, rather, as a means to help address people's concerns.

Hall and Loucks (1978) have found that teachers' concerns in school change programs begin with a focus on how they will be affected by the changes, move to a concern with implementing the task, and then to a determination of its impact on students. Plans for school change that address these real concerns have a greater chance of success. By involving people in the decision-making process and providing adequate training and follow-up, many of the concerns can be met.

\section{IMPLEMENTING A SCHOOL CONSULTATION MODEL}

Because the school change models just discussed have been developed to address generic school change, we are offering an adaptation designed for a project in which the goal of developing a consultation program already has been determined. Our implementation model has five steps.

\section{Stage 1: Establishing the Consultation Project}

At this intial stage of implementation, several preliminary steps must be taken, including: establishing the project's purpose and process, negotiating for resources, establishing a base of relationships, and forming a Consultation Task Force or Development Team. Administrators will have to be sold on the model.

As an initial means of enlisting support, a proposal should be developed detailing the expected costs, benefits, resources required, and training and inservice needs. Assessment of faculty concerns and perceptions of needed assistance with regard to mainstreaming also is helpful in presenting the rationale for the changes. Funds, expert support, and time may be needed for teacher training and project development. Assurance of adequate resource support is critical to ensure the viability of the project.

School boards, principals, parents, administrators, curriculum and instructional personnel, and education agencies are all potential sources of either support or opposition. Therefore, informing and communicating with these groups is essential to the project's success. Boyer (1985) has noted that although business and industry have recognized the value of involving all levels of employees in decision making and planning, education still operates largely in a top-down model. Reseach on quality of work life, when applied to education (Pratzner, 1984), speaks strongly to increased participation and decision making for teachers.

Beyond the obvious need to inform and communicate intentions, a Project Task Force can be formed, consisting of representatives of groups responsible for decision making and of other groups who may be affected by the project (regular educators, special educators, administrators, support personnel, and parents). The involvement of a variety of individuals will broaden the project's base of support and help to anticipate questions and concerns. Selecting individuals with power and prestige may encourage the participation of other reluctant parties on the planning committee.

The need for planning and implementation teams is useful both in central planning of the model and at the building level. Involving teachers, principals, and support personnel at the building level can encourage broader participation and avoid the attitude that the project is developed and planned only by top administrative and special education personnel.

\section{Stage 2: Planning}

Many critical decisions must be made by the Task Force or Planning Team. At this stage, decisions should be made regarding: (1) at which schools the program will take place, (2) what criteria will be used to select consulting teachers, (3) which regular teachers will be the focus of consultation, (4) which subjects or grades will be the targets of consultation, (5) what models will be used, (6) what student selection criteria will be used, and (7) how the project will be managed.

Developing a consultation program is a time-consuming process. Therefore, initial programs probably should be small in scope, and particular grades or subject areas should be focused upon. By starting small, the project will be more manageable, changes in the plan of operation can be made more easily and flexibly, and success can be demonstrated. This, of course, does not rule out plans and options for later expansion of the project.

Also at this stage a timeline for implementation of the program is needed. The project will require sufficient time for development, implementation, and evaluation. Planning at least one academic year prior to initiation of the program will allow time for teacher preparation and for material and curriculum development.

\section{Stage 3: Preparing for Implementation}

After decisions have been made about which models will be utilized and participants have been chosen, the next step 
is to develop products and train teachers. A consulting teacher program is not without its own particular paperwork; forms for documenting the use of staff time and for detailing the decisions made during consultation meetings are needed. Development of curriculum-based assessments to chart students' growth and classroom observation forms also are essential. This type of effort is best accomplished through team rather than individual teacher effort.

Teacher training is needed in the use of forms, methods of selecting students, and the interventions to be utilized. All faculty involved in the target schools should have some awareness of and preparation for implementation of the model. More intensive training may be given to those with direct responsibility, and in building the teams responsible for implementing the program in their sites.

\section{Stage 4: Implementation}

At this point the consulting model is carried out. Maintaining close communication between building teams at the various project sites can lend support to participants and help solve unexpected problems. The value of networks (Quinby, 1985 ) is evident at this stage. Teachers endeavoring to develop a consulting model may receive material support and assistance by participating in networks or teacher assistance teams.

Formative and summative data should be collected to evaluate the project's success. Possible sources of data include: (1) student growth in academic and affective areas, (2) program cost, (3) attitudes and skills of regular teachers, (4) attitude of administrators, (5) parent attitudes, and (6) consulting teachers' perceptions of success. Sufficient time (at least 18 months) must elapse before a project is thoroughly established and a true picture of its value is known.

\section{Stage 5: Maintenance}

Based on results of the evaluation, changes in the program might be indicated. Teachers should know that the initial model is a trial step, and that while commitment to the general principles is strong, alterations can be made if problems arise. Knowledge that the initial model is not final, that program success does not rest on initial perfection, and that changes will occur if needed can help reduce anxiety and resistance. Furthermore, at this stage plans to extend the project may be implemented, new participants trained, secure and stable resources obtained, and staff commitment renewed.
Although no plan can assure project success, the lack of careful project development may well doom it to failure. The steps in this model are offered only as suggestions that can be adapted to individual school or district needs. The important point is to develop a sequenced and patient approach to development of a consultation program.

\section{CONSULTING INTERVENTIONS}

Many suggestions have been made regarding the adaptation of instruction and instructional materials for mildly handicapped students in the mainstream (Blankenship \& Lilly, 1981; Lewis \& Doorlag, 1983; Wood, 1984). In evaluating and selecting strategies for consultation programs, two factors must be kept in mind: (1) Time demands on the teachers required by the suggested interventions must be reasonable, and (2) the interventions should address both the instructional needs of mildly handicapped students and be compatible with current knowledge regarding effective instruction.

Furthermore, though many interventions are valuable for mildly handicapped students (e.g., material adaptation or rewriting texts), we suggest that projects also formally adopt an intervention model. This will give direction to teacher training and intervention activities.

Regular educators, who are faced with large classes and a variety of instructional demands, may be unwilling and resistant to implement interventions for a variety of reasons. Interventions may be seen as being too complex, time consuming, aimed at only a few children, or disruptive to the general classroom program.

Bloom (1984) has recommended that research into means for improving student achievement focus on practical methods - those that the average teacher can learn in a brief period of time and require little additional cost or time. The same recommendation can be made regarding interventions adopted for handicapped students in the regular classroom. Interventions with the best chances for successful adoption are direct, benefit other children in the class, and are easy to implement and maintain.

Recent research into the learning characteristics and styles of mildly handicapped students have found that they spend less time on task (McKinney \& Speece, 1983; Feagans \& McKinney, 1981; Sherry, 1982); are more distractible than peers (Richey \& McKinney, 1978); have difficulty forming positive peer relationships (Bryan \& Bryan, 1977); and fail to deploy cognitive resources effectively (Alley \& Deshler, 1979; Lewis, 1983; Ross, 1976; Torgeson, 1980). These students also may fail to develop skills to an automatic level (Samuels, 1979; Sternberg \& Wagner, 1982). With these 
characteristics in mind, a major goal for the instruction of mildly handicapped students would be to increase the student's active engagement and provide direct instruction and sufficient practice opportunities for skill acquisition (Lewis, 1983; Wiens, 1983).

Fortunately, a variety of instructional procedures addressing these variables has been developed. Many of these recommendations also can be efficiently implemented in a regular setting. Research on effective teaching, while aimed at improving achievement for all students in the classroom, can have a significant effect on improving instruction for mildly handicapped students (Ausubel \& Robinson, 1969, Berliner, 1979, 1984; Bloom, 1984; Carnine \& Silbert, 1979, Englert, 1984; Hunter, 1984; Rosenshine, 1983). The use of cooperative learning groups and peer or cross-age tutoring fosters integration and acceptance of low performers in the classroom and also allows them to receive individual instruction and extra practice opportunities (Anderson, 1985; Idol-Maestas, 1983; Jenkins \& Jenkins, 1981, 1985; Johnson, Johnson, Holubec, \& Roy, 1984).

Other methods such as repeated readings (Samuels, 1979), sound-sheets (Idol-Maestas, 1983), learning strategies and study skills (Deshler, Schumaker, Lenz, \& Ellis, 1984) can be implemented in regular classroom settings. These blend well with the other cooperative learning, direct instruction, and peer tutoring models.

\section{Effective Teaching}

In the last few years research examining classroom variables correlated with higher achievement in students has been published (Berliner, 1979; Bloom, 1984; Brophy, 1983; Good \& Beckerman, 1978; Stallings \& Kaskowitz, 1974). Bloom (1984) reviewed research designed to examine the relative effects of a variety of instructional techniques on achievement. The techniques were compared to conventional instruction to determine their effectiveness in improving academic performance. The most powerful intervention was found to be tutorial or one-to-one instruction. Although this approach may not be feasible for the classroom teacher, other methods using one-to-one instruction, such as peer and cross-age tutoring, may fit well in a regular classroom setting.

The next most powerful variable was found to be the use of specific reinforcement. Providing students with contingent reinforcement was found to increase students' achievement 1.2 standard deviations over conventional instruction. Other variables yielding large effect sizes on achievement include the use of feedback and specific correctives, provision of cues and explanations, increasing student participa- tion, increasing time on task, cooperative learning, graded homework, improving classroom morale, teaching prerequisite skills, home environment interventions, and peer and cross-age tutoring.

Englert (1984) has summarized much of the effective change research and organized it into three major domains: classroom management, instructional organization, and teaching presentation. Many of the suggested teaching and organizational suggestions encompassed by this research have the effect of increasing allocated time, engaged time, student attention, and the clarity of instruction. By using these suggestions as part of the content for consultation, consulting special education teachers can focus on interventions that apply to the entire classroom, benefit the handicapped students, and be relatively easy to implement.

\section{Classroom Management}

Competencies noted by Englert (1984) as important in classroom management include classroom organization and the use of classroom rules and procedures. She suggested that teachers examine the physical arrangement of their classrooms so that students do not disrupt others when moving through the classroom during typical activities (e.g., sharpening pencils, turning in work). The teacher also is advised to examine procedures for dealing with nonacademic business, such as lunch count and attendance, by finding efficient means of completing these functions (perhaps through student helpers or aides). Also, procedures for dealing with students' requests for assistance, volunteering in class, and transitioning between activities should be examined and altered to make them less time consuming and more efficient.

By attending to these variables it is possible to increase the amount of time available in class for instruction. These suggestions, along with other means for reducing time spent in nonacademic tasks, can yield significant increases in academic achievement when that time is utilized appropriately.

The effective teaching literature also focuses on teaching and maintaining rules and procedures (Englert, 1984). It is suggested that teachers post and present rules and their consequences at the beginning of the school year. Teachers also are advised to model examples and nonexamples of those rules, require student rehearsal, give specific feedback on compliance, administer contingent praise, monitor rules closely, and terminate and consequate rule-breaking immediately.

Englert has suggested that students be involved in managing their own behavior. This can be accomplished by allowing students to participate in the selection of classroom rules 
and through implementing self-evaluation and charting procedures.

\section{Instructional Organization}

Suggestions in this area are directed at increasing the amount of engaged time students spend in instruction. Rosenshine (1980) has noted the importance of engaged time in increasing student academic achievement. Increases in engaged time can be accomplished through increasing student practice opportunities, presenting instructional activities related to students' stage of learning (Polloway, Payne, Patton, \& Payne, 1985), and involving students in direct teacher-mediated instruction.

Students at an acquisition stage of learning (low accuracy) should receive direct instruction and guided practice. Independent tasks and seatwork then would be given to students functioning at a proficiency or maintenance level on that skill, with an instructional focus on improving the rate of accuracy. Teachers can explain the rationale and objectives for their assignments and maintain student attention during direct lessons at the $90 \%$ level and during seatwork at the $80 \%$ level. Suggestions for fostering this level of attention include providing clear signals for the beginning and end of a lesson, providing students with advance organizers, circulating throughout the room during seatwork, and providing specific feedback to students on their academic performance.

\section{Teacher Presentation}

The final area addressed by Englert (1984) is teacher presentation of the lesson. Rosenshine (1983) has noted six teaching functions that teachers should include as part of their daily instruction: (1) daily review; (2) clear presentation of material, using demonstration and modeling; (3) guided practice, ensuring high levels of accuracy at the acquisition stage of learning, and asking a variety of higher order questions; (4) providing specific feedback and correctives to students; (5) independent work only after successful guided practice; and (6) weekly and monthly reviews.

Bloom (1984) found that the use of advance organizers during teaching presentations increases achievement. Ausubel and Robinson (1969) have described advance organizers as teaching activities or techniques teachers use to cue students in certain aspects of the learning task prior to the lesson's implementation. The major benefit in using advance organizers is to help students organize information for retention, retrieval, and comprehension. Lenz (1983) has iden- tified the following components that usually are associated with the use of advance organizers:

- Announcement of the benefits of the advance organizer.

- Topics and subtopics.

- Physical requirements needed for the learner and instructor to accomplish the tasks.

- Background information related to new learning.

- Concepts to be learned (specific or general).

- Examples for clarification of concepts to be learned.

- The organization or sequence in which the new information will be presented.

- Motivational information.

- Relevant vocabulary.

- Goals or outcomes desired. (p. 12)

Consulting teachers can use the findings of the effective teaching literature as a model by which to structure in-class observations of student environments. Discussing these areas with teachers and focusing on improving skills may help to improve the overall classroom climate, as well as the quality of instruction for all students. Changes in these domains are relatively easy to implement, increase students' actively engaged time, raise success rates, and improve the clarity of teacher presentations.

\section{Mastery Learning}

Mastery learning (Bloom, 1984) is an instructional procedure designed to be used in regular classrooms. In the mastery learning model (Guskey, 1984) teachers first analyze the content of their curriculum and organize it into units, usually of a 2-week duration. Units are broken into learning objectives, and tests directed at determining the acquisition of these goals and objectives then are developed.

After students receive instruction and study the content, they take the first formative test over the material. The criterion for passing is set, generally at $80 \%$ accuracy, and students who pass the test are given enrichment activities. Students who do not pass the test at $80 \%$ accuracy are provided with feedback and correctives. Guskey identified several types of correctives, including reteaching using the text or an alternative text, alternative material, workbooks, games, study groups, tutoring, learning kits, learning centers, and computer-assisted instruction. Students restudy the material using the correctives and then take a parallel test. Results of studies by Bloom (1984) show that the achievement of students in mastery learning was about one standard deviation above students receiving conventional instruction.

The value of a mastery learning model for mildly hand- 
icapped students is that it provides specific and direct feedback to the student, focuses learning on specific goals, gives students tangible evidence of their achievement, and results in a higher percentage of students reaching mastery of the curriculum. As in the effective teaching literature, changes in classroom practice incorporating mastery learning will benefit all students, may allow handicapped students to be maintained in the regular classroom curriculum, and are relatively easy to implement.

\section{Peer and Cross-Age Tutoring}

Instructional arrangements relying upon peers or older students to deliver specific instruction have been suggested by Jenkins and Jenkins $(1981,1985)$. Peer and cross-age tutoring programs can be used to deliver specific instruction in a wide variety of areas. They have the effect of increasing the amount of individualized instruction delivered to students and enabling more practice opportunities. Research has demonstrated significant skill improvements for both tutors and tutees in these programs (Jenkins \& Jenkins, 1985).

Jenkins and Jenkins (1981) have suggested several helpful steps in implementing effective peer and cross-age tutoring programs. Tutors should learn a specific instructional approach. Rather than simply asking students to study or drill together, effective tutoring programs are based on a direct model of instruction. Tutors should be taught methods of delivering direct instruction, following specific correctional procedures, providing appropriate reinforcement and feedback, and charting and measuring student progress.

A model-lead-test sequence (Carnine \& Silbert, 1979) is a powerful and easily mastered instructional procedure. Tutors can be taught this instructional sequence and use it to teach a variety of objectives including word attack, sight vocabulary, spelling, math facts, and math computation. Teachers have to thoroughly train tutors in the instructional pattern by modeling and demonstrating the skill and by engaging in role plays and role reversal. Periodic monitoring after skill acquisition is essential.

Jenkins and Jenkins (1981) also suggested that the curriculum should be the same as that taught in the regular classroom. If the goal of the program is to improve the functioning of handicapped students in the mainstream, instruction logically should support current classroom objectives. By focusing on content taught in the regular classroom, important curricular goals and objectives are less likely to be skipped. In addition, problems with transfer and generalization of skills can be minimized.

Other recommendations made by Jenkins and Jenkins include setting specific criteria for proficiency, scheduling frequent sessions (daily or twice daily), and teaching for a duration sufficient to promote learning (15- to 30-minute sessions). Furthermore, tutors need to recognize and demonstrate the importance of a positive learning atmosphere. This can be accomplished by demonstrating regard and respect for the learner. Teachers can emphasize warmth, body language, and similar factors. Tutors also will have to be taught how to measure student progress. With sufficient training they can collect information on accuracy or rate.

Tutoring programs offer the consultant a means of meeting handicapped students' needs for individual or small-group instruction in a regular classroom setting. The consulting teacher can take responsibility for tutor selection and training, working closely with the regular classroom teacher to ensure a match between instructed skills and the regular classroom program.

\section{Cooperative Learning Groups}

Cooperative learning groups (Johnson, Johnson, Holubec, \& Roy, 1984) have been found to be an effective approach for fostering both academic achievement (Johnson, Maruyama, Johnson, Nelson, \& Skon, 1981) and improving the social integration of mildly handicapped students (Anderson, 1985). Cooperative learning models seem to be effective with all types of learning tasks and at all grade levels (Johnson \& Johnson, 1983). Cooperation appears to be most effective, however, on tasks requiring high degrets of conceptual learning.

Cooperative learning has four basic components (Johnson et al., 1984). The first is positive interdependence. Students must depend upon and support each other if they are to complete the given task successfully. Positive interdependence is fostered through setting mutual goals, initiating division of labor among team members, assigning students different roles in completing the assignments, dividing materials and resources among team members, and providing joint rewards for team performance.

The second basic element in cooperative learning is faceto-face interaction. Students must be taught how to interact with each other in a positive, supportive manner.

The third basic element in cooperative learning is individual accountability for learning the assignment. Although students' scores may be combined in some models (e.g., Student Team Achievement Divisions), the mastery level of each student in the team is assessed and recorded.

The fourth element in cooperative learning is that students must learn and use appropriate interpersonal skills. Teachers must model and instruct students in positive social interactions-how to correct, reinforce, acknowledge, and evaluate their peers. 
Another important feature of cooperative learning models is that groups or teams must be heterogeneous; each team is composed of students with different levels of achievement. Groups also may contain students from different socioeconomic and ethnic groups.

Johnson et al. (1984) have noted six teacher roles in implementing cooperative learning groups: (1) specify the lesson objectives, (2) make decisions about placing students into groups, (3) assign students to groups, (4) arrange the room to promote interaction, (5) prepare the instructional materials and promote interdependence, and (6) assign students specific roles to ensure positive interdependence.

Slavin (1983) has researched and developed cooperative learning models including Student Teams Achievement Divisions and Teams-Games-Tournaments. Other cooperative learning models have been developed by Slavin, Leavey, and Madden (1982), Aronson (1978), and Johnson and Johnson (1975).

In the Student Teams Achievement Division model (Slavin, 1983), students are assigned to heterogeneous teams composed of four to five members. The teacher introduces new material to the class, and team members study worksheets. After time for practice, students take quizzes. During the quiz, students are not allowed to help each other.

Students' individual scores are recorded, but team scores are computed by determining how much each student's test score exceeds or falls below the student's previous test average. Students scoring their previous average contribute 5 points to the group score. For each point their test score exceeds their previous average, students earn one extra point (to a maximum of 10 points) assigned to the group score. Students scoring $100 \%$ contribute 10 points automatically. Students earn fewer points if their test falls below their previous average. For each point below their previous test average, one point is subtracted from the base of 5 .

Cooperative learning groups require the same attention to development as does a peer or cross-age tutoring model, and teachers must work closely with students to teach appropriate cooperation skills. Among the many benefits of this model, it addresses the lack of acceptance that mildly handicapped students often experience, and it generates a positive classroom atmosphere. It also increases the practice opportunities available for students and promotes their active participation and engagement.

\section{Learning Strategies}

Many recent instructional programs for mildly handicapped students have focused upon metacognitive strategies. Metacognition has been defined as one's ability to regulate cognitive bahavior (Flavell, 1977). The object of many metacognitive interventions is to instruct students in specific strategies that enable them to better acquire, store, manipulate, retrieve, and express information (Alley \& Deshler, 1979).

This approach is based on principles of cognitive-behavior modification (CBM), which is built upon research findings in the area of cognitive psychology, private speech, and instructional practices (Harris, 1982). The basic appeal of this approach is that it has been applied successfully (Deshler, Schumaker, Lenz, \& Ellis, 1984), can be taught in various educational settings (Deshler, Schumaker, Alley, Warner, \& Clark, 1982), and addresses the passive learning characteristics attributed to students with learning disabilities (Wiens, 1983).

In varied formats the instructional procedures usually incorporate: (1) modeling of the task by the teacher, (2) verbal description of task components by the students, and (3) implementing private speech to fade overt verbal cues. Selfinstruction is the core component in CBM procedures designed to influence metacognitive processes.

Deshler, Alley, Warner, and Schumaker (1981) have developed an eight-step instructional process for teaching learning strategies:

Step 1. Analysis of the current learning habit.

Step 2. Description of the learning strategy to be used by the student.

Step 3. Modeling of the new strategy by the teacher.

Step 4. Verbal rehearsal of the steps involved in the learning strategy.

Step 5. Student practice in controlled material.

Step 6. Student practice in classroom material.

Step 7. Posttest and obtaining a commitment to generalize.

Step 8. Generalization. (pp. 416-418)

Similar self-instructional procedures have been developed and used for a variety of skills in the areas of attention to task, social skills, and academic tasks (Meichenbaum, 1977; Hallahan \& Sapona, 1983; Deshler, Schumaker, \& Lenz, 1984).

A key component of many attention-to-task strategies is self-recording of performance (Hallahan, Lloyd, \& Stoller, 1982). In teaching students to monitor their own attention to task, the instructor is responsible for: (1) operationally defining attending and non-attending behaviors, and (2) modeling the procedures of the strategy to be followed (Hallahan \& Sapona, 1983). An example of this procedure is: (1) the student is provided with a random signal that cues a self-instructional response; (2) the student is to ask himself 
or herself, "Was I paying attention?" and (3) the student records an evaluation of his or her on-task behavior.

Use of this strategy has produced the following results: (1) Self-monitoring of attention during academic work leads to increases in attentional behavior and, although not the focus of instruction, increases in academic productivity; (2) initial cueing activities (i.e., a recorded tone) are necessary; and (3) a self-recording response was found to be essential (Hallahan \& Sapona, 1983). The success and ease of implementation of this approach make it attractive to many classroom teachers. Placing the responsibility for attentionto-task activities with individual students alleviates a major concern of many regular educators - the perception that these students' individual demands will detract from instructional time for other students.

\section{Academic Strategies}

Application of CBM procedures to academic content areas has been widespread in recent years. Major areas of focus have been written language, reading, study skills, and mathematics (Sheinker, Sheinker, \& Stevens, 1984). The Kansas University Institute for Research in Learning Disabilities (KUIRLD) has concentrated its efforts on developing learning strategies in three major domains:

1. Acquisition Strand. Strategies in this strand enable students to gain information from written material.

2. Storage Strand. Strategies are suggested to assist in the organization, storage, and retrieval of information.

3. Expression and Demonstration of Competence Strand. Strategies apply to completion of assignments, test taking, and written expression.

Researchers at KUIRLD have developed specific learning strategies within each strand to assist students in "learning how to learn" (Alley \& Deshler, 1979). To date, this learning strategies curriculum consists of 15 specific strategies that can be incorporated into a variety of academic settings. For other applications of CBM procedures in academic areas, the reader is directed to the reviews developed by Harris (1982) and Sheinker, Sheinker, and Stevens (1984). A major benefit in employing strategies such as these is that they address areas of concern stated by classroom teachers themselves (Deshler, Schumaker, Alley, Warner, \& Clark, 1982). The ability to provide teachers with successful approaches to instruction can enhance mildly handicapped students' opportunity for success within the mainstream.

\section{SUMMARY}

Although the instructional and implementation suggestions in this article by no means exhaust the approaches and strategies that are potentially useful in a consultation program, we hope they will be helpful in developing a more specific model. The value of cooperative planning and decision making in the development of a school change process cannot be underestimated. In synthesizing quality of work life literature and effective schools research, Pratzner (1984) contended that the quality and effectiveness of our schools can be improved by utilizing participatory management approaches and innovations that rely on greater cooperation and involvement of employees in management and production.

Strategies that also focus on greater participation and engagement of students in the learning process will help to promote greater relevance and higher achievement (Pratzner, 1984). The integration and acceptance of mildly handicapped students in mainstream settings may well be enhanced by the adoption of cooperative learning strategies, as well as strategies that address the variables noted in the effective teaching literature: increasing engaged time, providing feedback and reinforcement, giving sufficient guided practice opportunities and frequent reviews.

\section{REFERENCES}

Alley, G., \& Deshler, D. (1979). Teaching the learning disabled adolescent: Strategies and methods. Denver: Love Publishing.

Aloia, G. (1983). Special educators' perceptions of their roles as consultants. Teacher Education \& Special Education, 6, 83-87.

Anderson, M. (1985). Cooperative group tasks and their relationship to peer acceptance and cooperation. Journal of Learning Disabilities, 18 , 83-86.

Anderson-Inman, L., Walker, H., \& Purcell, J. (1984). Promoting the transfer of skills across settings. In W. Heward, T. Heron, D. Hill, \& J. Trap-Porter (Eds.), Focus on behavior analysis in education (pp. 17-37). Columbus, OH: Charles E. Merrill.

Aronson, E., (1978). The jigsaw classroom. Beverly Hills, CA: Sage.

Ausubel, D., \& Robinson, F. (1969). School learning: An introduction to educational psychology. New York: Holt, Rinehart \& Winston.

Bergan, J. (1977). Behavioral consultation. Columbus, OH: Charles E. Merrill.

Berliner, D. (1979). Tempus educare. In P. Peterson \& H. Walderg (Ed.), Research on teaching: Concepts, findings and implications (pp. 120135). Berkeley: McCutchan.

Berliner, D. (1984). The half-full glass: A review of research on teaching. In P.L. Hosford (Ed.), Using what we know about teaching (pp. 51-77). Alexandria, VA: Association for Supervision \& Curriculum Development.

Bickel, W., \& Bickel, D. (1986). Effective schools, classrooms, and instruction: Implications for special education. Exceptional Children, $52,489-500$.

Blankenship, C., \& Lilly, S. (1981). Mainstreaming students with learning and behavior problems. New York: Holt. 
Bloom, B. (1984). The 2 sigma problem: The search for methods of group instruction as effective as one-to-one tutoring. Educational Researcher, 13, 4-16.

Boyer, E., (1985). In the aftermath of excellence. Educational Leadership, $42,10-13$

Brokes, A. (1975). A process model of consultation. In C. Parker (Ed.), Psychological consultation: Helping teachers meet special needs (pp. 185-203). Reston, VA: Council for Exceptional Children.

Brophy, J. (1983). Classroom organization and management. Elementary School Journal, 83, 254-285.

Bryan, T., \& Bryan, J. (1977). The social-emotional side of learning disabilities. Behavioral Disorders, 2, 141-145.

Carnine, D., \& Silbert, J. (1979). Direct instruction reading. Columbus, $\mathrm{OH}$ : Charles E. Merrill.

Cipani, E. (1985). The three phases of behavioral consultation: Objectives, intervention, and quality assurance. Teacher Education \& Special Education, 8, 144-152.

Cohen, J. (1982). Handbook of resource room teaching. Rockville, MD: Aspen.

DeBoer, A. (1986). The art of consulting. Chicago: Arcturus Books.

Deshler, D., Alley, G., Warner, M., \& Schumaker, J. (1981). Instructional practices for promoting skill acquisition and generalization in severely learning disabled adolescents. Learning Disability Quarterly, 4, 415421.

Deshler, D., Schumaker, J., Alley, G., Warner, M., \& Clark, F. (1982). Learning disabilities in adolescent and young adult populations: Research implications. Focus on Exceptional Children, 15(1), 1-12.

Deshler, D., Schumaker, J., \& Lenz, B. (1984). Academic and cognitive interventions for LD adolescents: Part 1. Journal of Learning Disabilities, 17, 108-117.

Deshler, D., Schumaker, J., Lenz, B., \& Ellis, E. (1984). Academic and cognitive interventions for LD adolescents: Part II. Journal of Learning Disabilities, 17, 170-179.

Dunn, L. (1968). Special education for the mildly retarded-Is much of it justifiable? Exceptional Children, 35, 5-22.

Englert, C. (1984). Measuring teacher effectiveness from the teacher's point of view. Focus on Exceptional Children, 17, 1-16.

Evans, S. (1980). The consultant role of the resource teacher. Exceptional Children, 46, 402-403.

Feagans, L., \& McKinney, J. (1981). The pattern of exceptionality across domains in learning disabled children. Journal of Applied Developmental Psychology, 1, 313-328.

Flavell, J. (1977). Cognitive development. Englewood Cliffs, NJ: PrenticeHall.

Friend, M. (1984). Consulting skills for resource teachers. Learning Disability Quarterly, 7, 246-250.

Friend, M. (1985). Training special educators to be consultants: Considerations for developing programs. Teacher Education \& Special Education, $8,115-120$.

Gallagher, P. (1985). Inservice! A mandated special education course and its effects on regular classroom teachers. Teacher Education \& Special Education, 8, 59-65.

Gallessich, J. (1982). The profession and practice of consultation. San Francisco: Jossey-Bass.

Gerber, M. (1986). Cognitive-behavioral training in the curriculum: Time, slow learners, and basic skills. Focus on Exceptional Children, 18, 1-12.

Goldstein, H., Moss, J., \& Jordan, L. (1965). The efficacy of special class training on the development of mentally retarded children (U.S. Office of Education, Cooperative Project Number 619). Urbana, IL: University of Illinois.

Good, T., \& Beckerman, T. (1978). Time on task: A naturalistic study in sixth-grade classrooms. Elementary School Journal, 78, 193-201.

Goodlad, J. (1984). A place called school. New York: McGraw-Hill.

Guskey, T. (1984). Implementing mastery learning. Belmont, CA: Wadsworth.

Haight, S., \& Molitor, D. (1983). A survey of special education teacher consultants. Exceptional Children, 49, 550-553.

Hall, G., \& Loucks, S. (1978). Teacher concerns as a basis for facilitating and personalizing staff development. Teachers College Record, 80 , 36-53.

Hallahan, D., Lloyd, J., \& Stoller, L. (1982). Improving attention with self-monitoring: A manual for teachers. Charlottesville, VA: University of Virginia Learning Disabilities Research Institute.

Hallahan, D., \& Sapona, R. (1983). Self-monitoring of attention with learning-disabled children: Past research and current issues. Journal of Learning Disabilities, 16, 573-636.

Harris, K. (1982). Cognitive-behavior modification: Application with exceptional students. Focus on Exceptional Children, 15, 1-16.

Hawisher, M., \& Calhoun, M. (1978). The resource room. Columbus, $\mathrm{OH}$ : Charles E. Merrill.

Heller, K.A., Holtzman, W.H., \& Messick, S. (1982). Placing children in special education: A strategy for equity. Washington, DC: National Academy Press.

Heron, T.E., \& Harris, K.D. (1982). The educational consultant: Helping professionals, parents, and mainstreamed students. Boston: Allyn \& Bacon.

Hobbs, N. (1975). Issues in the classification of children (Vols. 1-2). San Francisco: Jossey-Bass.

Hudson, F., Graham, S., \& Warner, M. (1979). Mainstreaming: An examination of the attitudes and needs of regular classroom teachers. Learning Disability Quarterly, 2, 58-62.

Hudson, F., Reisberg, L., \& Wolf, R. (1983). Changing teachers' perceptions of mainstreaming. Teacher Education \& Special Education, 6, $18-24$.

Hunter, M. (1984). Knowing, teaching, and supervising. In P.L. Hosford (Ed.), Using what we know about teaching (pp. 169-192). Alexandria, VA: Association for Supervision \& Curriculum Development.

Idol-Maestas, L. (1983). Special educator's consultation handbook. Rockville, MD: Aspen.

Idol-Maestas, L., Friend, M., Smith-Davis, J., Prothro, H., Johnson, S., \& Fairchild, R. (1985). The consultation portfolio. Reno, NV: Disse$\mathrm{min} /$ Action.

Idol-Maestas, L., Lloyd, S., \& Lilly, M. (1981). Implementation of a noncategorical approach to direct service and teacher education. Exceptional Children, 48, 213-219.

Idol-Maestas, L., \& Ritter, S. (1985). A follow-up study of resource/consulting teachers: Factors that facilitate and inhibit teacher consultation. Teacher Education \& Special Education, 8, 121-131.

Ito, H. (1980). Long-term effects of resource room programs on learning disabled children's reading. Journal of Learning Disabilities, 13, 322326.

Jenkins, J., \& Jenkins, L. (1981). Cross age and peer tutoring: Help for children with learning problems. Reston, VA: Council for Exceptional Children.

Jenkins, J., \& Jenkins, L. (1985). Peer tutoring in elementary and secondary programs. Focus on Exceptional Children, 17, 1-12.

Johnson, D., \& Johnson, R. (1975). Learning together and alone: Cooperation, competition and individualization. Englewood Cliffs, NJ: Prentice-Hall

Johnson, D., \& Johnson, R. (1983). The socialization and achievement crises: Are cooperative learning experiences the solution? In L. Bickman (Ed.), Applied social psychology annual 4. Beverly Hills, CA: Sage.

Johnson, D., Johnson, R., Holubec, E., \& Roy, P. (1984). Circles of learning. Washington, DC: Association for Supervision \& Curriculum Development.

Johnson, D., Maruyama, G., Johnson, R., Nelson, D., \& Skon, L. (1981). Effects of cooperative, competitive, and individualistic goal structure on achievement: A meta-analysis. Psychological Bulletin, 89, 47-62.

Knight, M., Meyers, H., Paolucci-Whitcomb, P., Hasazi, S., \& Nevin, A. (1981). A four year evaluation of consulting teacher service. Behavioral Disorders, 6, 92-100.

Knight, N. (1976). Working relationships that work. Teaching Exceptional Children, 8, 113-115. 
Lenz, B. (1983). Using advance organizers. Pointer, 27, 11-13.

Lewis, R. (1983). Learning disabilities and reading: Instructional recommendations from current research. Exceptional Children, 50, 230-240.

Lewis, R., \& Doorlag, D. (1983). Teaching special students in the mainstream. Columbus, $\mathrm{OH}$ : Charles E. Merrill.

Lilly, M. (1972). A training-based model for special education. Exceptional Children, 37, 745-749.

Lilly, M., \& Givens-Ogle, L. (1981). Teacher consultation: Present, past, and future. Behavioral Disorders, 6, 73-77.

Loucks-Horsley, S. \& Hergert, L. (1985). An action guide to school improvement. Washington, DC: A.S.C.D.

Madden, N., \& Slavin, R. (1983). Mainstreaming students with mild handicaps: Academic achievement and social outcomes. Review of Educational Research, 53, 519-569.

McClellan, E., \& Wheatley, W. (1985). Project RETOOL: Collaborative consultation training for post-doctoral leadership personnel. Teacher Education \& Special Education, 8, 159-163.

McKinney, J., \& Speece, D. (1983). Classroom behavior and the academic progress of learning disabled students. Journal of Applied Developmental Psychology, 4, 149-161.

Meichenbaum, D. (1977). Cognitive behavior: An integrative approach. New York: Plenum Press.

Mercer, C. (1983). Students with learning disabilities (2nd ed.). Columbus, $\mathrm{OH}$ : Charles E. Merrill.

Miller, T., \& Sabatino, P. (1978). An evaluation of the teacher consultant model-An approach to mainstreaming. Exceptional Children, 45, 8691.

Neel, R.S. (1981). How to put the consultant to work in consulting teaching. Behavioral Disorders, 6, 78-81.

Paolucci-Whitcomb, P., \& Nevin, A. (1985). Preparing consulting teachers through a collaborative approach between university faculty and fieldbased consulting teachers. Teacher Education \& Special Education, 8, 132-143.

Polloway, E., Payne, J., Patton, J., \& Payne, R. (1985). Strategies for teaching retarded and special needs learners (3rd ed.). Columbus, $\mathrm{OH}$ : Charles E. Merrill.

Pratzner, F. (1984). Quality of school life: Foundation for improvement. Educational Researcher, 13, 20-25.

Quinby, N. (1985). Improving the place called school: A conversation with John Goodlad. Educational Leadership, 42, 16-19.

Reger, R. (1979). Learning disabilities: Futile attempts at a simplistic definition. Journal of Learning Disabilities, 12, 529-532.

Richey, D., \& McKinney, J. (1978). Classroom behavior patterns in learning disabled children. Journal of Learning Disabilities, 11, 38-43.

Rosenshine, B. (1980). How time is spent in elementary classrooms. In C. Denham \& A. Lieberman (Eds.), Time to learn (pp. 107-126). Washington, DC: National Institute of Education.

Rosenshine, B. (1983). Teaching functions in instructional programs. Elementary School Journal, 85, 335-352.

Ross, A. (1976). Psychological aspects of learning disabilities and reading disorders. New York: Basic Books.

Ryor, J. (1978). 94-142-The perspective of regular education. Learning Disability Quarterly, 1, 6-14.

Salvia, J., \& Ysseldyke, J.E. (1985). Assessment in special and remedial education (3rd ed.). Boston: Houghton-Mifflin.

Samuels, S.J. (1979). The method of repeated reading. Reading Teacher, $32,403-408$.

Sheinker, A., Sheinker, J., \& Stevens, L. (1984). Cognitive strategies for teaching the mildly handicapped. Focus on Exceptional Children, 17, $1-16$.
Sherry, L. (1982). Non-task oriented behaviors of educable mentally retarded, emotionally handicapped, and learning disabled students. Educational Research Quarterly, 4, 19-29.

Sindelar, P.T., \& Deno, S.L. (1978). The effectiveness of resource programming. Journal of Special Education, 12, 17-28.

Slavin, R.E. (1983). Cooperative learning. New York: Longman.

Slavin, R.E., Leavey, M., \& Madden, N.A. (1982). Effects of student teams and individualized instruction on student mathematics achievement, attitudes, and behaviors. Paper presented at the annual convention of the American Educational Research Association, New York.

Sparks, G., Nowakowski, M., Hall, B., Alec, R., \& Imrick, J. (1985). School improvement through staff development. Educational Leadership, 42, 59-61.

Speece, D.L., \& Mandell, C.J. (1980). Resource room support services for regular teachers. Learning Disability Quarterly, 3, 49-53.

Stallings, J., \& Kaskowitz, D. (1974). Follow through classroom observation evaluation, 1972-73. Menlo Park, CA: Stanford Research Institute.

Stainback, W., \& Stainback, S. (1984). A rationale for the merger of special and regular education. Exceptional Children, 51, 102-111.

Sternberg, R.J., \& Wagner, R.K. (1982). Automatization failure in learning disabilities. Topics in Learning \& Learning Disabilities, 2, 1-11.

Tharpe, R. (1975). The triadic model of consultation. In C. Parker (Ed.), Psychological consultation in the schools: Helping teachers meet special needs. Reston, VA: Council for Exceptional Children.

Tombari, M., \& Davis, R. (1979). Behavior consultation. In G.D. Phye \& D.J. Reschly (Eds.), School psychology: Perspectives and issues (pp. 281-307). New York: Academic Press.

Torgeson, J. (1980). Conceptual and educational implications of the use of efficient task strategies by learning disabled children. Journal of Learning Disabilities, 13, 364-371.

Vaac, N.A. (1975). Long term effects of special class intervention for emotionally disturbed children. In H. Dupont (Ed.), Educating emotionally disturbed children: Readings. New York: Holt, Rinehart \& Winston.

Vasa, S.T. (1982). The special education resource teacher as a consultant: Fact or fantasy? Paper presented at the Sixth Annual Meeting of the Council for Exceptional Children, Houston. (ERIC Document Reproduction Service No. ED218918)

Wang, M., \& Birch, J. (1984). Comparison of a full-time mainstreaming program and a resource room approach. Exceptional Children, 51, 33-40.

Wiederholt, J., Hammill, D., \& Brown, V. (1983). The resource teacher. Austin, TX: Pro-Ed.

Wiens, W. (1983). Metacognition and the adolescent passive learner. Journal of Learning Disabilities, 16, 144-148.

Wixson, S.E. (1980). Two resource room models for serving learning and behavior disordered pupils. Behavioral Disorders, 5, 116-125.

Wood, J. (1984). Adapting instruction for the mainstream: A sequential approach to teaching. Columbus, $\mathrm{OH}$ : Charles E. Merrill.

Ysseldyke, J. (1979). Assessing the learning disabled youngster: The state of the art (Research Report No. 1). Minneapolis: University of Minnesota, Institute for Research on Learning Disabilities.

Ysseldyke, J. (1983). Current practices in making psychological decisions about learning disabled students. In G. Senf \& J. Torgeson (Eds.), Annual Review of Learning Disabilities: Vol 1. A Journal of Learning Disabilities Reader. Chicago, IL: Professional Press.

Ysseldyke, J.E., \& Algozzine, B. (1983). LD or not LD: That's not the question! Journal of Learning Disabilities, 16, 29-31. 


\section{ALERT}

\section{NEW BOOK}

Mental Retardation:

Nature, Cause, and Management (2nd edition)

George S. Baroff

This is a comprehensive work covering the nature of mental retardation and intelligence, its etiology, personality and developmental factors, psychological considerations, services ranging from infant and preschool programs through adolescent and adult concerns, and management of behavior problems. The chapters on personality problems (including those associated with autism) and behavior problems are new to this second edition. And the text has expanded discussions on intelligence and on sexuality.

An extensive bibliography is included, and illustrative/ graphical material is used liberally to clarify the narrative. Reviews in the AAAS Science Books and Films and Contemporary Psychology have commended this book as "one of the best," "readable," "up-to-date," and "top of the list." It is definitely worth a look by human services professionals and educators in the field.

The book is hardbound, 541 pages, and available from Hemisphere Publishing Corporation, 79 Madison Avenue, New York, NY 10016.

\section{MEETINGS}

-American Speech and Hearing Association

November 21-24, 1986

Detroit, Michigan

-Association for Children and Adults

With Learning Disabilities

February 25-28, 1987

San Antonio, Texas

-Pan American Conference on Rehabilitation and Special Education

March 15-18, 1987

Acapulco, Mexico

(Contact: Richard Beck 512/381-2287)

- Council for Exceptional Children

April 20-24, 1987

Chicago, Illinois

\section{FREE APPROPRIATE PUBLIC} EDUCATION: The Law and Children with Disabilities

by $H$. Rutherford Turnbull, III, University of Kansas

Here is a complete definitive resource covering legislation, case law techniques, statutory techniques, due process, parent participation, and cites over 500 court cases. A muchneeded reference.

8602/hardback/New 2nd edition ISBN 0-89108-125-9 \$29.95

\section{DICTIONARY OF SPECIAL}

\section{EDUCATION AND REHABILITATION}

by Leo J. Kelly, Valdosta State College

\section{Glenn Vergason, Georgia State University}

This reference defines terminology important to these fields. The definitions are written clearly, concisely, and noncategorically, with equal attention to each area.

8502/paper/New 2nd edition

ISBN 0-89108-168-2 \$14.95

\section{COMMUNICATING WITH PARENTS OF EXCEPTIONAL CHILDREN}

by Roger L. Kroth, University of New Mexico

The content covers listening, comparing perceptions, the parent-teacher conference, disseminating information, reporting progress, parent group meetings, problem solving, and other topics of contemporary concern.

\section{ADMINISTRATION OF SPECIAL EDUCATION}

by Clifford Howe, University of lowa

This handy book discusses legal concerns, finance, organization, roles, staff development, evaluation, and administrative arrangements.

8117/hardback

ISBN 0-89108-106-2 \$24.95

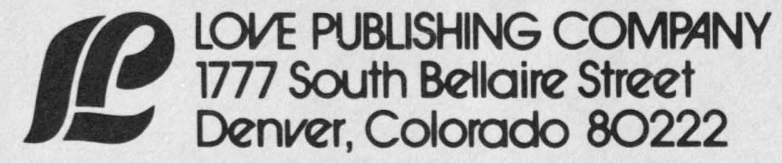




\section{STATISTICAL UPDATE}

\section{Educational Environments by Handicapping Condition,}

School Year 1983-84*

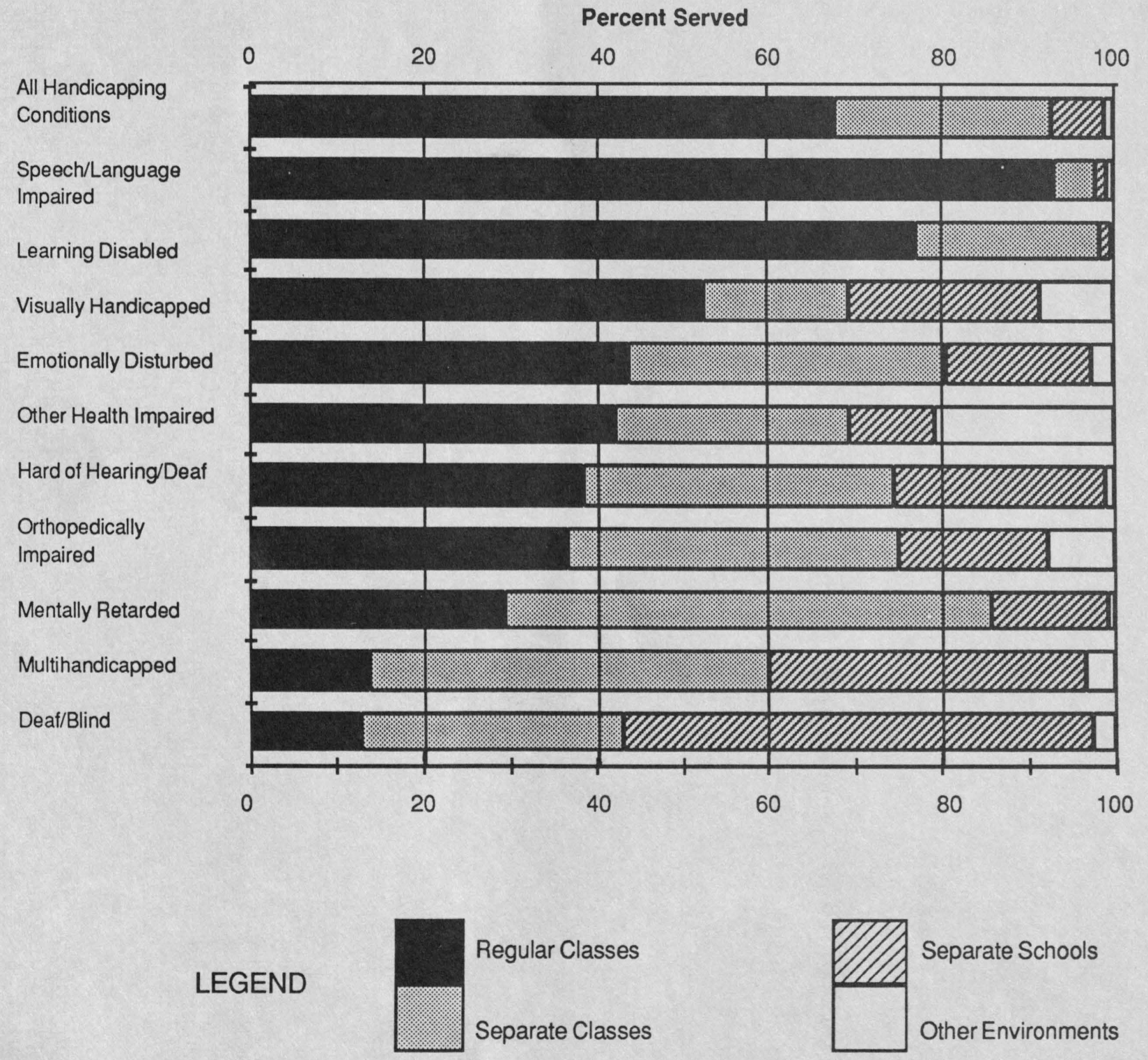

*Does not include 15,349 children reported noncategorically.

Source: Eighth Annual Report to Congress on the Implementation of the Education of the Handicapped Act, Vol. 1: To Assure the Free Appropriate Public Education of All Handicapped Children. U.S. Dept. of Education, 1986. 